Wanzala et al., Afr J Tradit Complement Altern Med., (2017) 14 (6): 72-77

https://doi.org/10.21010/ajtcam.v14i6.8

\title{
IN VITRO AND IN VIVO ANTI-TRYPANOSOMAL ACTIVITIES OF METHANOL EXTRACT OF AZADIRACHTA INDICA STEM-BARK
}

\author{
Everlyne N. Wanzala*', Nicholas K. Gikonyo ${ }^{1}$, Grace Murilla ${ }^{2}$, Mercy Githua ${ }^{3}$, Ahmed Hassanali $^{4}$ \\ ${ }^{1}$ Department of Pharmacy \& Complementary/Alternative Medicine, Kenyatta University, P.O Box 43844 - \\ 00100 Nairobi, Kenya. ${ }^{2}$ Biotechnology Research Institute, Kenya Agricultural and Livestock Research \\ Organization, P.O Box 362, Kikuyu, Kenya. ${ }^{3}$ Department of Chemistry, Jomo Kenyatta University of \\ Agriculture and Technology, P.O Box 62000-00200 Nairobi, Kenya. ${ }^{4}$ Department of Chemistry, Kenyatta \\ University, P.O Box 43844 - 00100 Nairobi, Kenya.
}

*Corresponding Author E-mail: wanzalaeverlyne@ gmail.com

\begin{tabular}{|l|}
\hline \multicolumn{1}{|c|}{ Article History } \\
Received: Mar. 01, 2017 \\
Revised Received: Jun. 11, 2017 \\
Accepted: Jun. 13, 2017 \\
Published Online: Nov. 15, 2017 \\
\hline
\end{tabular}

\begin{abstract}
Background: Current chemotherapeutic agents for the treatment of African trypanosomiasis have become largely ineffective, necessitating the search for alternative compounds. The objective of this study was to evaluate in vitro antitrypanosomal activities of methanol extracts of parts of Azadirachta indica against Trypanosoma brucei rhodesiense, Trypanosoma brucei brucei and Trypanosoma evansi and establish the in vivo efficacy of the most active extract.

Materials and methods: Maceration of powdered leaves, stem bark and root bark of the plant in methanol afforded three extracts. In vitro assays were carried out with the extracts on the three trypanosome strains in 96-well microtitre plates at concentration ranges of $4000-1000 \mu \mathrm{g} / \mathrm{ml}$. The most active extract was assayed in vivo using Trypanosoma brucei rhodesiense infected Swiss albino mice at doses of 100, 200 and $400 \mathrm{mg} / \mathrm{kg}$ body weight. Melarsoprol and suramin served as positive controls. The infected untreated group served as the negative control. Parasitaemia levels, packed cell volume, body weight changes and mean survival period of all groups were monitored throughout the experimental period.

Results: Methanol extract of the stem bark of A.indica was most active in vitro against all the three trypanosome strains (MIC values of $9.93 \pm 1.88,16.25 \pm 0.92$ and $9.97 \pm 0.44 \mu \mathrm{g} / \mathrm{ml}$ for $T$. b. rhodesiense, $T$. b. brucei and $T$. evansi, respectively). The extract showed optimum activity at $400 \mathrm{mg} / \mathrm{kg}$ and was comparable to the positive control groups. Parasitaemia levels were kept at a significantly low level $(\mathrm{p}<0.05)$ by the extract compared to the negative control. Notably, there was no significant difference $(\mathrm{p}>0.05)$ in mean survival time of mice treated with the extract at $400 \mathrm{mg} / \mathrm{kg}$ and the positive controls.

Conclusion: In vitro and in vivo anti-trypanosomal activities of the methanol extract of A. indica stem bark could be attributed to the presence of constituents of moderate polarity.
\end{abstract}

Key words: Anti-trypanosomal activity, Azadirachta indica, Trypanosoma brucei brucei, Trypanosoma brucei rhodesiense, Trypanosoma evansi

\section{Introduction}

African trypanosomiasis is caused by single-celled protozoa of the genus Trypanosoma. Trypanosoma brucei, T. $b$. gambiense and T. b. rhodesiense are the main causative agents of human African trypanosomiasis whereas animal African trypanosomiasis is caused by T. b. brucei, T. congolense, T. vivax, T. evansi and T. equiperdum (Brun, Hecker, \& Lun, 1998; Patrick et al., 2012; Swallow, 2000). African trypanosomiases impact negatively on the entire economy of Africa by weakening the health of both humans and animals (John, Rachid, Damian, Glyn, \& Stephen, 2012). Parasite resistance to the existing chemotherapeutic agents compounded by the poor prospect for a vaccine due to antigenic variation of the parasite has spurred the search for alternative compounds for African trypanosomiasis (Florencia \& Stefan, 2011). 
However, there has been no significant resistance observed in clinical isolates and laboratory selection for some agents such as suramin. A possible explanation could lie in the fact that suramin unselectively inhibits enzymes and receptors, and therefore could inhibit multiple targets (Fairlamb, 2003). The current study aimed at investigating in vitro and in vivo anti-trypanosomal activities of methanol extracts of $A$. indica plant parts.

Azadirachta indica has been used as traditional medicine for the management of various diseases for decades due to its medicinal properties (Brototi \& Kaplay, 2011; Kumar, Debasis, Goutam, \& Chandra, 2010). Extracts of A. indica have been reported to exhibit various pharmacological activities (Kumar et al., 2010). In the current study, treatment of $T$. b. rhodesiense infected Swiss white mice with the methanol extract of $A$. indica stem bark revealed that the extract was efficacious at a dose level of $400 \mathrm{mg} / \mathrm{kg}$.

\section{Materials and Methods \\ Plant collection and extraction}

Leaves, stem- and root-barks of $A$. indica were collected from Pwani University (Kilifi, North coast of Kenya). The plant species was identified by a taxonomist and a voucher specimen (Specimen No. EN/05/2012) deposited at the herbarium of the department of Pharmacy \& Complementary/ Alternative Medicine, Kenyatta University and also at the East African Herbarium, National Museums of Kenya, Nairobi. The air dried plant parts were ground into fine powders followed by extraction at room temperature by maceration for 24 hours in methanol. The extracts were partitioned between water and dichloromethane (DCM). The DCM phases were combined and concentrated in vacuo.

\section{Trypanosomes}

Cryopreserved stabilates of Trypanosoma b. rhodesiense (KETRI 3438), T. b. brucei (EATRO 2400) and T. evansi (KETRI 2454) were obtained from the Biotechnology Research Institute, Kenya Agricultural and Livestock Research Organization, (KALRO) trypanosome bank. The stabilates were thawed at room temperature, suspended in cold phosphatesaline-glucose (PSG) buffer $\mathrm{pH} 8.0$ and injected intraperitonially into immunosuppressed donor mice for multiplication. At the first peak of parasitaemia, donor mice were anaesthetized using carbon dioxide and blood collected from the heart of the mice using a syringe containing ethylene diamine tetra acetic acid (EDTA) as anticoagulant. The parasitaemia count was quantified using a haemocytometer and the blood was diluted appropriately with PSG buffer to obtain the required inoculum dose of $1 \times 10^{4}$ trypanosomes $/ \mathrm{ml}$.

\section{In vitro assays for anti-trypanosomal activity}

The in vitro antitrypanosomal assays were carried out in 96-well microtitre plates according to the method by Räz et al., (1997). The first stock solutions of the extracts were prepared in distilled water for the water-soluble samples at 20 $\mathrm{mg} / \mathrm{ml}$ or in dimethyl sulfoxide (DMSO) (at $1 \mathrm{mg} / 100 \mu \mathrm{l}$ ) for the water-insoluble samples. The extracts were assayed on the three trypanosome strains at concentration ranges of $4000-1000 \mu \mathrm{g} / \mathrm{ml}$. Each plate was examined with an inverted microscope to determine the minimum inhibitory concentration (MIC) which is the concentration at which no cell with a normal morphology and/or motility was found in comparison to the negative control cultures (Githua et al., 2010).

\section{Experimental animals}

Randomly selected healthy female Swiss white mice weighing between 20 - $25 \mathrm{~g}$ were obtained from Biotechnology Research Institute, KALRO small animal breeding unit. They were dewormed using injectable ivermectin at $0.1 \mathrm{ml}$ per mouse and were acclimatized for 14 days during which they were maintained on a diet of commercial mice pellets (mice pellets®, Unga Ltd, Nairobi, Kenya) and water was provided ad libitum. All experimental protocols and procedures used on animals during the study were reviewed and approved by the Institutional Animal Care and Use Committee (IACUC) of Biotechnology Research Institute, KALRO.

\section{Determination of acute toxicity}

Twenty mice were randomly placed into four groups of five animals each. Each group received treatment of the following doses of the methanol extract of the stem bark intraperitoneally, daily for four days: Group i (100 mg/kg body weight (bwt); Group ii (200 mg/kg bwt); and Group iii (400 mg/kg bwt). Group iv was given water only. Animals were initially observed closely for a period of 10-15 minutes following administration of the test drug for signs of acute toxicity. The mice were then closely monitored throughout the 4 days of administration and two weeks of experiment. Changes in posture, breathing, food intake and water consumption patterns of the treated mice were noted on a daily basis. Excessive 
weight loss and changes of packed cell volume (PCV) of more than two-fold compared with the control group of mice over the 2 weeks period was considered a key indicator of declining health due to drug toxicity (Mbaya, Ibrahim, God, \& Ladi, 2010).

\section{Determination of in vivo efficacy}

Thirty five mice were randomly divided into seven groups of five mice each. Each experimental mouse was intraperitonially injected $0.2 \mathrm{ml}$ of PSG buffer containing an inoculum dose of $1 \times 10^{4}$ trypanosomes $/ \mathrm{ml}$ of $T$. $b$. rhodesiense (KETRI 3438) from donor mice. The mice were then treated as follows: Group i; i.p. treatment of $100 \mathrm{mg} / \mathrm{kg}$ bwt of extract, 24 hours post-infection (PI) for four days; Group ii ; i.p. treatment with $200 \mathrm{mg} / \mathrm{kg}$ bwt of extract from 24 hours PI for four days; Group iii; i.p. treatment with $400 \mathrm{mg} / \mathrm{kg}$ bwt of extract from 24 hours PI for four days; Group iv; intraperitoneally treated using suramin $(5 \mathrm{mg} / \mathrm{kg}$ bwt) from 24 hours PI for three days (positive control I), Group v; intraperitoneally treated using melarsoprol $(3.6 \mathrm{mg} / \mathrm{ml})$ from 24 hours PI for three days (positive control II), Group vi; infected and given water ad-libitum with no extract (negative control), Group vii; uninfected and untreated (blank group). Group vii was included in the study for purposes of reference especially on the survival of the mice throughout the experimental period (60 days). Determination of in vivo efficacy was based on the changes in the levels of parasitaemia, packed cell volume (PCV) and weights of the animals during the experimental period.

\section{Parasitaemia examination}

The level of parasitaemia was determined daily for five days after the first treatment, then every two days for the remaining days of the experimental period. A drop of blood was collected from the mouse tail, placed on a clean slide, covered with a cover slip and viewed under the microscope at $\mathrm{x} 400$ magnification using the method of Herbert and Lumsden (1976).

\section{Determination of packed cell volume (PCV)}

Packed cell volume (PCV) was determined by bleeding tail vein of mice and filling three-quarters full heparinized capillary tubes with 50-60 $\mu \mathrm{l}$ of the blood. The sealed tubes were centrifuged at $10000 \mathrm{rpm}$ for 5 minutes in a haematocrit centrifuge, and the height of the red blood cell column was measured by use of haematocrit reader. The percentage of the total blood volume occupied by red blood cell mass was considered as the PCV.

\section{Mean Survival Time}

The survival time for each mouse was recorded by daily checking the cages for mortality. The number of dead mice was recorded throughout the experimental period. The average survival time was then calculated.

\section{Data Analysis}

Statistical Package for Social Science (SPSS) version 21 was used for data analysis and the values obtained were expressed as mean \pm standard error of mean (SE). The significant differences between variables were compared by one-way ANOVA followed by Student Newmann Keul's test (SNK). P values less than 0.05 were considered significant.

\section{Results}

The in vitro activities were classified according to Hoet et al.(Hoet et al., 2004). It emerged that the stem bark extract was the most active exhibiting anti-trypanosomal effects against all the three strains used in the study (Table 1).

Table 1: In vitro anti-trypanosomal activity (MIC) of methanol extracts of A. indica

\begin{tabular}{llll}
\hline Plant Part/ & \multicolumn{3}{c}{ MIC $\pm \mathrm{SE}(\mu \mathrm{g} / \mathrm{ml})$ against } \\
Compound & T. b. rhodesiense & T. . brucei & T. evansi \\
\hline Leaf & $51.98 \pm 1.21$ & $48.17 \pm 0.11$ & $22.13 \pm 0.14$ \\
Stem bark & $9.93 \pm 1.88$ & $16.25 \pm 0.92$ & $9.97 \pm 0.44$ \\
Root bark & $23.50 \pm 0.07$ & $18.38 \pm 0.25$ & $32.70 \pm 0.09$ \\
\hline Melarsoprol & $0.003 \pm 0.001$ & $0.005 \pm 0.002$ & $0.003 \pm 0.001$ \\
Suramin & $1.54 \pm 0.09$ & $1.66 \pm 0.10$ & $1.51 \pm 0.13$ \\
\hline
\end{tabular}




\section{Acute toxicity studies}

No animal mortality was observed during the 14 days of experimentation. There were no visible signs of acute toxicity among the animals treated with the extract at the doses used in the study.

\section{Effect of the methanol extract of $A$. indica on parasitemia of $T$. $b$. rhodesiense infected mice}

There was a delay in the commencement of parasite appearance in the extract treated groups (Table 2). The optimum activity of the extract was obtained at $400 \mathrm{mg} / \mathrm{kg}$, at which there was no significant difference ( $>0.05$ ) with positive control groups. Compared with the negative control, the $400 \mathrm{mg} / \mathrm{kg}$ extract kept parasitaemia at a significantly low level $(\mathrm{p}<0.05)$ throughout the experimental period.

Table 2: Effect of methanol extract of $A$. indica stem-bark on parasitemia of $T$. $b$. rhodesiense (KETRI 3438) infected mice

\begin{tabular}{|c|c|c|c|c|c|c|c|c|}
\hline \multirow{2}{*}{$\begin{array}{l}\text { Treatment } \\
\text { group }\end{array}$} & \multicolumn{7}{|c|}{ Parasitemia level (log number)/mL } & \multirow[b]{2}{*}{ D56 } \\
\hline & D7 & D14 & D21 & D28 & D35 & D42 & D49 & \\
\hline $100 \mathrm{mg} / \mathrm{kg}$ & $3.90 \pm 1.76^{\mathrm{ab}}$ & $6.48 \pm 1.64^{b}$ & $6.00 \pm 1.62^{b c}$ & $6.72 \pm 1.71^{\mathrm{c}}$ & $6.96 \pm 1.75^{\mathrm{c}}$ & $5.90 \pm 1.75^{\mathrm{b}}$ & $5.40 \pm 1.29^{c}$ & $4.80 \pm 1.96^{\mathrm{c}}$ \\
\hline $200 \mathrm{mg} / \mathrm{kg}$ & $2.88 \pm 1.62^{\mathrm{ab}}$ & $4.44 \pm 1.82^{\mathrm{ab}}$ & $5.04 \pm 2.07^{b}$ & $5.10 \pm 1.09^{b c}$ & ${ }^{c} 5.08 \pm 2.16^{b c}$ & $3.00 \pm 1.07^{\mathrm{b}}$ & $2.80 \pm 0.80^{\mathrm{b}}$ & $3.00 \pm 1.07^{\mathrm{bc}}$ \\
\hline $400 \mathrm{mg} / \mathrm{kg}$ & $0.00 \pm 0.00^{\mathrm{a}}$ & $1.62 \pm 0.32^{\mathrm{a}}$ & $1.62 \pm 0.32^{\mathrm{ab}}$ & $1.38 \pm 0.14^{\mathrm{ab}}$ & $\mathrm{b} 1.68 \pm 0.80^{\mathrm{ab}}$ & $1.74 \pm 0.41^{\mathrm{ab}}$ & $1.80 \pm 0.18^{\mathrm{ab}}$ & $1.74 \pm 0.41^{\mathrm{ab}}$ \\
\hline $3.6 \mathrm{mg} / \mathrm{kg} \mathrm{Mel}$ & $0.00 \pm 0.00^{\mathrm{a}}$ & $0.00 \pm 0.00^{\mathrm{a}}$ & $0.00 \pm 0.00^{\mathrm{a}}$ & $0.00 \pm 0.00^{\mathrm{a}}$ & $0.00 \pm 0.00^{\mathrm{a}}$ & $0.00 \pm 0.00^{\mathrm{a}}$ & $0.00 \pm 0.00^{\mathrm{a}}$ & $0.00 \pm 0.00^{\mathrm{a}}$ \\
\hline $5 \mathrm{mg} / \mathrm{kg}$ Sur & $0.00 \pm 0.00^{\mathrm{a}}$ & $0.00 \pm 0.00^{\mathrm{a}}$ & $0.00 \pm 0.00^{\mathrm{a}}$ & $0.00 \pm 0.00^{\mathrm{a}}$ & $0.00 \pm 0.00^{\mathrm{a}}$ & $0.00 \pm 0.00^{\mathrm{a}}$ & $0.00 \pm 0.00^{\mathrm{a}}$ & $0.00 \pm 0.00^{\mathrm{a}}$ \\
\hline Negative control & $6.60 \pm 1.66^{\mathrm{b}}$ & $8.34 \pm 0.11^{\mathrm{b}}$ & $8.64 \pm 0.29^{c}$ & $8.48 \pm 0.28^{c}$ & $8.55 \pm 0.28^{\mathrm{c}}$ & $9.00 \pm 0.00^{\mathrm{c}}$ & - & - \\
\hline
\end{tabular}

Values are mean $\pm \mathrm{SEM}$; $\mathrm{SE}=$ standard error; $\mathrm{n}=5 ; \mathrm{D}=$ day; Mel = melarsoprol; Sur = suramin; negative control = infected untreateated; - implies that mice were dead; values with the same superscript(s) down the column do not differ significantly at $\mathrm{p}<0.05$

\section{Effect of extract on packed cell volume of $T$. b. rhodesiense infected mice}

There was no significant difference in maintaining the PCV values in the animals treated with the extract at 400 $\mathrm{mg} / \mathrm{kg}$ and the positive control groups (melarsoprol and suramin) throughout the study period ( $\mathrm{p}>0.05)$. Packed cell volume $(\mathrm{PCV})$ values in the negative control group started declining and remained lower than the values of the extract treated groups (Table 3).

Table 3: Effect of methanol extract of $A$. indica stem-bark on packed cell volume of $T$. b. rhodesiense (KETRI 3438) infected mice

\begin{tabular}{|c|c|c|c|c|c|c|c|c|}
\hline \multirow{2}{*}{$\begin{array}{l}\text { Treatment } \\
\text { group }\end{array}$} & \multicolumn{6}{|c|}{ Packed cell volume (PCV(\%)) of mice } & \multirow[b]{2}{*}{ D49 } & \multirow[b]{2}{*}{ D56 } \\
\hline & D7 & D14 & $\mathrm{D} 21$ & D28 & D35 & D42 & & \\
\hline $100 \mathrm{mg} / \mathrm{kg}$ & $47.00 \pm 0.71^{\mathrm{a}}$ & $45.40 \pm 2.73^{\mathrm{ab}}$ & $44.20 \pm 4.47$ & 0.2. & 5.50 & $\mathrm{~b}_{48.33 \pm 3.61^{\mathrm{b}}}$ & $45.33 \pm 4.11^{\mathrm{a}}$ & $48.00 \pm 0.00^{\mathrm{a}}$ \\
\hline $200 \mathrm{mg} / \mathrm{kg}$ & $49.80 \pm 1.87^{\mathrm{a}}$ & $45.60 \pm 2.20^{\mathrm{ab}}$ & $48.60 \pm 2.23^{\mathrm{ab}}$ & b $50.20 \pm 1.11^{\mathrm{b}}$ & $46.20 \pm 2.87^{\mathrm{ab}}$ & $51.00 \pm 3.22^{b}$ & $50.67 \pm 2.21^{\mathrm{bc}}$ & $49.67 \pm 3.39^{\mathrm{a}}$ \\
\hline $400 \mathrm{mg} / \mathrm{kg}$ & $50.00 \pm 1.24^{\mathrm{ab}}$ & $49.60 \pm 1.81^{\mathrm{ab}}$ & $48.80 \pm 1.24^{\mathrm{ab}}$ & b $50.40 \pm 0.81^{\mathrm{b}}$ & $50.00 \pm 2.35^{\mathrm{b}}$ & $50.40 \pm 2.75^{\mathrm{b}}$ & $51.20 \pm 1.84^{\mathrm{bc}}$ & $51.00 \pm 1.10^{\mathrm{ab}}$ \\
\hline $3.6 \mathrm{mg} / \mathrm{kg} \mathrm{Mel}$ & $52.40 \pm 1.69^{b}$ & $51.80 \pm 1.21^{\mathrm{b}}$ & $53.20 \pm 0.37^{\mathrm{b}}$ & $53.60 \pm 0.80^{\mathrm{b}}$ & $52.80 \pm 0.86^{\mathrm{b}}$ & $54.80 \pm 0.49^{\mathrm{b}}$ & $52.80 \pm 0.37^{\mathrm{c}}$ & $52.90 \pm 0.58^{b}$ \\
\hline $5 \mathrm{mg} / \mathrm{kg}$ Sur & $52.00 \pm 1.05^{\mathrm{b}}$ & $52.60 \pm 0.51^{\mathrm{b}}$ & $51.40 \pm 0.51^{\mathrm{b}}$ & $52.20 \pm 1.16^{\mathrm{b}}$ & $53.20 \pm 0.86^{\mathrm{b}}$ & $55.20 \pm 0.73^{b}$ & $54.60 \pm 0.75^{\mathrm{c}}$ & $53.80 \pm 0.80^{\mathrm{b}}$ \\
\hline Negative contro & $147.40 \pm 1.03^{\mathrm{a}}$ & $43.00 \pm 1.34^{\mathrm{a}}$ & $42.00 \pm 1.76^{\mathrm{a}}$ & $40.75 \pm 4.96^{\mathrm{a}}$ & $39.67 \pm 2.85^{\mathrm{a}}$ & $37.50 \pm 2.21^{\mathrm{a}}$ & - & - \\
\hline
\end{tabular}

Values are mean $\pm \mathrm{SE} ; \mathrm{SE}=$ standard error; $\mathrm{n}=5$; $\mathrm{D}=$ day; Mel = melarsoprol; Sur $=$ suramin; negative control $=$ infected untreateated; - implies that mice were dead; values with the same superscript(s) down the column do not differ significantly at $\mathrm{p}<0.05$

\section{Effect of stem-bark extract of $A$. indica on body weight of $T$. $b$. rhodesiense infected mice}

At the optimum dose of $400 \mathrm{mg} / \mathrm{kg}$ the extract treated animals and positive control groups showed comparable increment in body weight (Figure 1). 


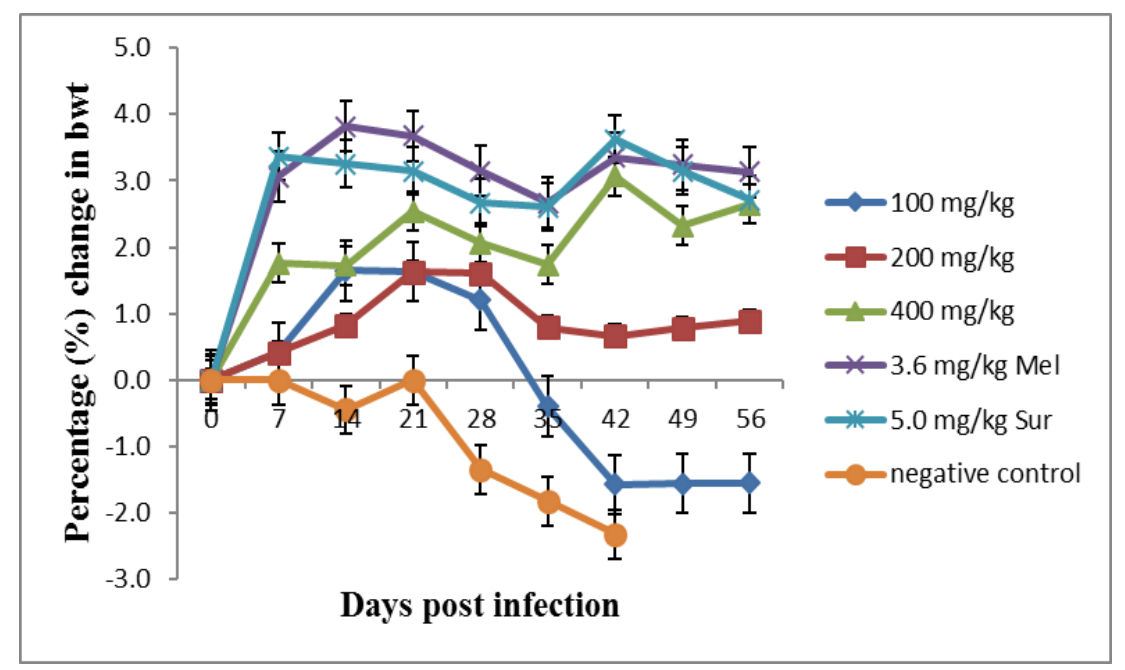

Figure 1: Trends of percentage (\%) change in body weight of $T$. b. rhodesiense (KETRI 3438) infected mice treated intraperitoneally with methanol extract of $A$. indica stem bark; values are mean $\pm \mathrm{SE} ; \mathrm{n}=5$; negative control $=$ infected untreated; Mel = melarsoprol; Sur = suramin

\section{Effect on mean survival time of $T$. $b$. rhodesiense infected mice}

Animals treated with the extract at various dose levels survived for longer time compared to the infected-untreated control (33.00 \pm 3.08 days). The survival times between the extract treated animals at higher doses $(200 \mathrm{and} 400 \mathrm{mg} / \mathrm{kg})$ differed significantly with the negative control group. The mean survival time of animals treated with the extract at 400 $\mathrm{mg} / \mathrm{kg}$ was comparable to those in positive control groups.

Table 4: Effect of methanol extract of $A$. indica stem-bark on mean survival time of $T$. b. rhodesiense (KETRI 3438) infected mice

\begin{tabular}{|c|c|c|c|c|c|}
\hline \multirow{2}{*}{$\begin{array}{l}\text { Treatment } \\
\text { group }\end{array}$} & \multicolumn{3}{|c|}{ Number of mice } & \multirow{2}{*}{$\begin{array}{l}\text { Percentage of } \\
\text { mice cured }\end{array}$} & \multirow{2}{*}{$\begin{array}{l}\text { Mean survival } \\
\text { time (days } \pm \mathrm{SE})\end{array}$} \\
\hline & treated & survived & cured & & \\
\hline $100 \mathrm{mg} / \mathrm{kg}$ & 5 & 1 & 0 & 0 & $46.2 \pm 5.44^{\mathrm{ab}}$ \\
\hline $200 \mathrm{mg} / \mathrm{kg}$ & 5 & 3 & 1 & 20 & $51.8 \pm 5.14^{\mathrm{bc}}$ \\
\hline $400 \mathrm{mg} / \mathrm{kg}$ & 5 & 5 & 4 & 80 & $59.6 \pm 0.40^{\mathrm{c}}$ \\
\hline $3.6 \mathrm{mg} / \mathrm{kg} \mathrm{Mel}$ & 5 & 5 & 5 & 100 & $60.0 \pm 0.00^{c}$ \\
\hline $5 \mathrm{mg} / \mathrm{kg}$ Sur & 5 & 5 & 5 & 100 & $60.0 \pm 0.00^{c}$ \\
\hline Negative control & 5 & 0 & 0 & 0 & $33.0 \pm 3.08^{\mathrm{a}}$ \\
\hline Blank & 5 & 5 & 5 & 100 & $60.0 \pm 0.00^{c}$ \\
\hline
\end{tabular}

$\mathrm{SE}=$ standard error; Mel = melarsoprol; Sur = suramin; negative control = infected untreated; blank = uninfected untreated; values with the same superscript(s) do not differ significantly at $\mathrm{p}<0.05$.

\section{Discussion}

Anti-trypanosomal activity of $A$. indica reported in the present study is comparable to a report by Mbaya $e t$ al. (Mbaya et al., 2010) which showed that A. indica stem bark possesses in vitro trypanocidal effect against $T$. $b$. brucei. A study on the leaf extract of $A$. indica by Githua et al. (2010) showed that the extract was active in vitro against procyclic forms of $T$. $b$. rhodesiense.

Results from in vivo efficacy study indicated that at a higher dose of $400 \mathrm{mg} / \mathrm{kg}$, the methanol extract of $A$. indica stem bark maintained parasitaemia in $T$. b. rhodesiense infected mice at significantly lower levels as compared to the negative control indicating the presence of anti-trypanosomal constituents in the extract. However, a steady rise in parasitaemia levels was observed in animals treated with the extract at lower doses of 100 and $200 \mathrm{mg} / \mathrm{kg}$ from D14 to D56, indicating that the ability of the extract to control parasitaemia levels of infected mice was dose-dependent. A similar trend was observed in the ability of the extract to extend survival period of infected mice. These observations demonstrate that the anti-trypanosomal activity of the extract could be improved by using a higher dose or isolated active compounds in the extract.

The extract significantly reduced weight loss and decline in packed cell volume (PCV) associated with parasitaemia. Packed cell volume and weight loss are common and critical features in the pathogenesis of African 
trypanosomiasis contributing to morbidity and mortality (Kagira, Thuita, \& Ngotho, 2006). Infected mice treated with $A$. indica extract in the current study showed significantly higher levels in PCV compared to the negative control (infected untreated) group which can be ascribed to an enhanced resistance of erythrocyte haemolysis (Kagira et al., 2006).

These findings are in agreement with a previous study which reported that $A$. indica exhibited encouraging in vivo trypanocidal activity with a reduction in the level of T. brucei parasitemia in mice (Mbaya et al., 2010). A similar study (Ngure et al., 2009) revealed that the aqueous extract of Azadirachta indica was active against Trypanosoma brucei rhodesiense, indicating that polar constituents of the stem bark could be contributing to the antitrypanosomal effects of the plant part.

\section{Conclusion}

The current study established that the methanol extract of $A$. indica stem bark possess both in vitro and in vivo antitrypanosomal activity against $T$. brucei rhodesiense. Isolation and characterization of constituents of the extract, which is currently on-going research, could yield a potential antitrypanosomal lead compound.

\section{Acknowledgements}

The authors acknowledge the financial support from National Commission for Science Technology and Innovation (NACOSTI), Kenya, under grant No. NCST/ST\&I/RCD/4th Call PhD/164.

Conflict of Interest: Authors declare that there is no conflict of interest

\section{References}

1. Brototi, B., \& Kaplay, R. D. (2011). Azadirachta indica (Neem): Its Economic utility and chances for commercial planned plantation in Nanded District. Int. J. Pharma, 1, 100 - 104.

2. Brun, R., Hecker, H., \& Lun, Z. R. (1998). Trypanosoma evansi and T. equiperdum: distribution, biology, treatment and phylogenetic relationship (a review). Vet Parasitol, 79, 95 - 107.

3. Fairlamb, A. H. (2003). Chemotherapy of human African trypanosomiasis: current and future prospects. Trends in parasitol, 19(11), 488-494.

4. Florencia, L. G., \& Stefan, M. (2011). Vaccination against trypanosomiasis: Can it be done or is the trypanosome truly the ultimate immune destroyer and escape artist? Hum Vaccin, 7(11), 1225-1233.

5. Githua, M., Hassanali, A., Keriko J., Murilla, G., Ndungu, M., \& Nyagah, G. (2010). New Antitrypanosomal tetranotriterpenes from Azadirachta indica. Afr. J. Trad. CAM., 7, 207 - 213.

6. Herbert, W. J., \& Lumsden, W. H. R. (1976). Trypanosoma brucei : A rapid matching method for estimating the host's parasitemia. Exp. Parasitol., 40, 427 - 431.

7. Hoet, S., Opperdoes, F., Brun, R., Adjakidje, V., Quetin, L., \& Eclercq, J. (2004). In vitro antitrypanosomal activity of ethnopharmacologically selected Beninese plants. J Ethnopharmacol, 91, $37-42$.

8. John, W. H., Rachid, O., Damian, K., Glyn, A. V., \& Stephen, J. T. (2012). Modeling the control of trypanosomiasis using trypanocides or insecticide-treated livestock. PLoS Negl Trop Dis, 6, 1615.

9. Kagira, J. M., Thuita, J. K., \& Ngotho, M. (2006). Haematology of Trypanosoma brucei rhodesiense infection on vervet monkeys. Afr J Health Sci., 13, $59-65$.

10. Kumar, P. S., Debasis, M., Goutam, G., \& Chandra, S. P. (2010). Biological action and medicinal properties of various constituent of Azadirachta indica (Meliaceae)" an Overview. Annals of Biological Research, 1, 24 - 34.

11. Mbaya, A. W., Ibrahim, U. I., God, O. T., \& Ladi, S. (2010). Toxicity and potential antitrypanosomal activity of ethanolic extract of Azadirachta indica (Meliaceae ) stem bark: An in vivo and in vitro approach using Trypanosoma brucei. J. Ethnopharmacol, 128, $495-400$.

12. Ngure, R. M., Bosire, O., Stephen, M. K., William, W., Ronald, G. M., Kibugi, J. K., \& Francis, N. W. (2009). Antitrypanosomal effects of Azadiracta indica (neem) extract on Trypanosoma brucei rhodesiense-infected mice. Eastern J of Med, 14, $2-9$.

13. Patrick, M., Epco, H., Veerle, L., Victor, K., Jean-Jacques, M., Pascal, L., \& Marleen, B. (2012). Human African trypanosomiasis diagnosis in first-line health services of endemic countries, a systematic review. PLoS Negl Trop Dis, 6, 1919.

14. Räz, B., Iten, M., Grether-Bühler, Y., Kaminsky, R., \& Brun, R. (1997). The Alamar Blue assay to determine drug sensitivity of African trypanosomes (T. b. rhodesiense and T. b. gambiense) in vitro. Acta Trop, 68, $139-147$.

15. Swallow, B. M. (2000). Impacts of trypanosomiasis on African agriculture. Paper presented at the PAAT Technical and Scientific Series, Rome. 